\title{
ENGINEERING HARMONY UNDER MULTI-CONSTRAINT OBJECTIVES: THE PERSPECTIVE OF META-ANALYSIS
}

\author{
Qiankun WANG, Weiwei ZUO*, Qianyao LI \\ School of Civil Engineering and Architecture, Wuhan University of Technology, Wuhan, China
}

Received 28 April 2019; accepted 22 August 2019

\begin{abstract}
Harmony is the process of coordinated development between the elements, subsystems and the environment in each Engineering stage of the engineering implementation. Quality, duration, cost and risk are the key factors to achieve engineering harmony. Clarifying the influencing factors of engineering harmony and its mechanism can improve the possibility of success. The meta-analysis method is used to carry out a restudy of existing researches of engineering harmony. First, quality, duration, cost and risk are selected as the variables of achieving engineering harmony. Second, the paper collects 29 existing researches including many countries and regions around the world on the relationship between the variables and engineering harmony. Third, each value is calculated and corrected according to literature coding. Forth, publication deviation and total effect test are checked. Finally, the research conclusions and engineering management implications are given based on the results of meta-analysis. The results show that quality objective, duration objective, cost objective and risk management objective all have positive impact on achieving engineering harmony. The engineering type has no regulatory effect on positive impact of the duration objective and cost objective, but has regulatory effect on positive impact of the quality objective and risk management objective on the engineering harmony.
\end{abstract}

Keywords: engineering harmony, scheduling, quality, lifestyle costing, risk management, meta-analysis.

\section{Introduction}

Engineering harmony is the process of conflict resolution between various elements, systems and the environment (Garwood \& Poole, 2018). Clarifying the influencing factors of engineering harmony and its mechanism can effectively improve the possibility of success. To some extent, many international scholars have clarified the key elements of engineering harmony (Assaf \& Al-Hejji, 2006; Marzouk \& El-Rasas, 2014; Mohammed \& Isah, 2012). Since the engineering management objectives are mostly evaluated comprehensively from the perspective of quality, duration, cost, risk, etc., the existing researches generally believe that there is a direct relationship between the objectives, such as quality, duration, cost, risk, and the realization of engineering harmony (Chen, Jin, Xia, Wu, \& Skitmore, 2016; Liu, Xie, Xia, \& Bridge, 2017; Molenaar \& Dai, 2014). The existing literature has carried out a lot of research on the relationship between quality, duration, cost, risk and the realization of engineering harmony, but there are still great controversies about the specific mechanism of the impact. From the perspective of participants in engineering, each stakeholder has different standards for achieving project harmony (M. M. Musa, Amirudin, Sofield, \& M. A. Musa, 2015). The final customer of the project believes that the achievement of goals such as quality, duration, cost and risk is an important standard to measure engineering harmony (Pinto \& Slevin, 2013). The project managers believe that the process of achieving the quality goal, duration goal, cost goal and risk management goal is more conducive to achieving the engineering harmony (Wilson, 2015). Toor and Ogunlana (2009) also believe that the engineering should meet the expectations of all stakeholders in terms of quality, duration, cost and risk, and minimize disputes and conflicts to achieve the engineering harmony. From the macro and micro perspective of engineering management, the macro engineering harmony only involves the results of the operation stage (Lim \& Mohamed, 1999). On the micro level, it includes the quality, duration, cost and risk of each construction stage to promote the success of the project (Zhang, Liu, Tan, Jiang, \& Zhu, 2018). This means that during the implementation of the project, it is not only necessary to focus on the success of the project over a long time, but also to

*Corresponding author. E-mail: whutzuo@126.com 
pay attention to the engineering harmony of the various implementation stages in the short term.

Quality, duration, cost and risk are the key factors to achieve engineering harmony. They are not independent of each other. Through theoretical and empirical studies, domestic and foreign scholars have extensively discussed the tradeoffs of quality, duration, cost and risk in the process of achieving engineering harmony. Due to the complexity of the influencing factors, there is no single best measurement method at present. Early researches mainly explained the relationship between quality, duration, cost, risk and engineering harmony from the perspective of project success. For example, Sambasivan and Soon (2007) determined the key factors of cost, duration and quality in project sustainable development by quantifying factors contributing to the success of $17 \%$ construction projects in Malaysia. In terms of theoretical research, Azaron, Katagiri, and Sakawa (2007) developed an analysis model of time-cost-risk tradeoff to promote engineering harmony by using optimal control theory in Markov Network. These studies provide valuable data and theoretical basis for exploring the realization of engineering harmony through coordination of quality, duration, cost and risk, but the research conclusion is worth discussing. The specific reasons include: firstly, the standards selected in the relevant empirical survey are not consistent, including the uncertainty of measurement caused by subjectivity of the definition of quality, risk and other factors (Idiake, Oke, \& Shittu, 2015). Secondly, the research conclusions based on different perspectives such as project managers, project characteristics, project teams, and different research methods have a paradox, and there is a lack of research on the impact on engineering harmony from the perspective of multi-factor combination (Sanchez \& Terlizzi, 2017). Thirdly, the existing researches have many characteristics such as engineering type difference and regional difference. Therefore, it is necessary to make a comprehensive study on the specific mechanism of quality, duration, cost, and risk affecting engineering harmony, so as to minimize various deviations and ensure the scientificity, objectivity and authenticity of the conclusion.

This paper attempts to focus on the existing research on the relationship between quality, duration, cost, risk and engineering harmony, which has differentiated conclusions and even paradoxes, and carries out a systematic study on engineering harmony under multi-objective constraints by using the method of meta-analysis.

\section{The basic assumptions}

As the most important and competitive factor in engineering management (Deshpande, Siddhalingeshwar, \& Ekabote, 2016), quality objective plays a crucial role in the economic benefits of projects and enterprises (Alger, 2013). Engineering construction is an extremely complex process, involving a wide range of factors (S. Qureshi, S. M. Qureshi, Ullah, Memon, \& Siddiqui, 2017), and there are many influencing factors that lead to quality objective, including material selection, mechanical category, topography and geology, hydrological conditions, meteorological changes, construction technology, operation method, management measures, etc. (Preethi \& Monisha, 2017). The purpose of engineering quality management is to guarantee the engineering quality level, to meet the requirements of the owner or the set standards and norms, to ensure the smooth implementation of contracts and plans in the engineering management process, and to guarantee the harmonious coexistence of the project and people, nature, environment, etc. (Foy, 2013). The value of the project can be measured by the quality level associated with the project (Liberatore \& Pollack-Johnson, 2013). The poor engineering quality will affect the construction period and cost. Therefore, it is necessary to control the engineering quality with the help of quality management, so as to achieve the harmonious development among the engineering, personnel management, engineering construction, and natural environment (Fu \& Zhang, 2016). To sum up, this paper proposes the following hypothesis:

$\mathrm{H} 1$ : the quality objective has positive impact on achieving engineering harmony.

The degree of novelty, complexity and technical uncertainty of different types of engineering is different, and the methods and difficulty of realizing engineering quality objective are also different (Frank, Sadeh, \& Ashkenasi, 2011). Different types of engineering have different requirements for quality management. With the increase of the quantity and scale of project organization, the requirements of quality objective for different types of projects have been improved, and higher requirements have been put forward for relevant project quality managers (Monghasemi, Nikoo, Fasaee, \& Adamowski, 2015). Improving work flexibility and organizational support can have a positive impact on the satisfaction of engineers from the perspective of work and family, which is conducive to the improvement of project quality and the promotion of engineering internal harmony (Wu, Duan, Zuo, Yang, \& Wen, 2016). Engineering projects are in a dynamic and open environment, and the constantly changing system environment requires the quality objective to be dynamically changed according to different stages of different project types. According to the different characteristics of quality management of different engineering types, coordination and priorities should be determined, quality target requirements should be defined, and the matching degree between quality target and project types should be improved, so as to promote the internal management harmony of engineering. To sum up, this paper proposes the following hypothesis:

$\mathrm{H} 2$ : the engineering type may influence the positive impact of the quality objective on engineering harmony.

Generally speaking, the construction cycle of the engineering is relatively long, and there are many factors affected. Various unexpected events will occur in the actual 
construction process, so there is often error between the actual completion time and the initial target period of the engineering (Jaśkowski \& Biruk, 2011). Delayed delivery of engineering is considered to be one of the most common problems. The failure of construction period management will affect the project's expected revenue and increase the financial cost. In the context of fierce competition in the engineering field, failure to complete the project in time may damage the credibility of the designer and the contractor, and the expected target may also be affected by construction delay. It can be seen that the realization of the construction period target is of great significance for promoting engineering harmony (Fernandez-Viagas \& Framinan, 2015). Time buffer can alleviate the changes caused by the complexity of engineering and the uncertainty of external environment (Russell, Liu, Howell, \& Hsiang, 2015). In order to effectively carry out construction schedule control, it is necessary to obtain the relevant status information regularly and timely (Feng, Wei, \& Zhang, 2015). Therefore, the duration target should not only ensure the implementation according to the project plan, but also dynamically adjust it according to the changes of internal and external environment, so as to realize the internal management and external environment harmony. To sum up, this paper proposes the following hypothesis:

H3: the duration objective has positive impact on achieving engineering harmony.

The duration target runs through all stages of the project life cycle, so it is necessary to make the time schedule according to the characteristics of different types of engineering (Jin, 2015). The destructive impact of random factors can be avoided to ensure that the actual construction process of the project meets the expected planning (Jaśkowski, 2015). The construction schedule is affected by the objective and subjective environment in many ways, and the impact size of different types engineering is different, and the random events are also different in the construction process. There are differences on resource limitations in different types of engineering. Under the resource constraints, project scheduling problem is related to project management level (Lin \& Hsiau, 2010), and the project duration shall be minimized on the basis of satisfying the priority relationship and resource constraints. Based on the operating conditions of different types of engineering, the construction period management is evaluated by multiple attributes, and the risk evaluation of construction duration can effectively optimize the duration objective and realize the internal management harmony (Fernandez-Viagas \& Framinan, 2014). To sum up, this paper proposes the following hypothesis:

$\mathrm{H} 4$ : the engineering type may influence the positive impact of the duration objective on engineering harmony.

The cost target control of engineering involves the multi-angle control of labor cost and material cost, domi- nant cost and recessive cost, which is a professional field with strong technical skills (Smith, 2016) and an important factor of engineering harmony (Mclean, Mcgovern, \& Davie, 2015; Schuh et al., 2018). Since the problem of continuous simulation of cost estimation has not been effectively solved, and the cost uncertainty of construction, transportation and other projects is very obvious (Chou, 2011), many cases of cost overruns emerge one after another, causing a lot of time waste, project disputes and disharmony. This greatly requires more effective cost targets. Relatively speaking, the cost target has greatly narrowed the gap between capital and technology, and corresponding systematic cost uncertainty analysis (SCUA) can reduce the random uncertainty of cost target and reduce the total operating cost. In addition, the cost objective will promote the engineering management to actively identify, analyze and manage the cost risks faced, to optimize the delivery quality and schedule deadline within the appropriate cost range, and to promote the project harmony finally (Toutounchian, Abbaspour, Dana, \& Abedi, 2018). To sum up, this paper proposes the following hypothesis: H5: the cost objective has positive impact on achieving engineering harmony.

Specific approaches to achieving cost objective are often difficult to cope with different types of engineering, as cost objective of different types engineering are often closely related to the professionals involved in project management and management mode (Smith, 2016). The project type mainly adjusts the impact of the cost target on the engineering harmony through three aspects. First, different project types determine different leadership styles of project managers. Research shows that different leadership styles are more likely to succeed in different types of cost management (Müller \& Turner, 2007). Second, different engineering types mean differentiated cost target control methods, which will push the cost target to achieve a lower cost status (Mota \& de Castro, 2017). Since the cost issues of engineering must be resolved dynamically within the agreed scope. The validity of cost target control can also be adjusted from the perspective of project scale, duration, extension, and project manager power by engineering types (Sanchez \& Terlizzi, 2017). Finally, the different information management system is applicable to different project types. Digital technologies and tools provide tremendous opportunities for cost management. Different types of information systems can be differentiated to reflect the quality, speed, accuracy, value and complexity of the realization of cost objective, and will change the relationship between cost objective and engineering harmony (Smith, 2016). To sum up, this paper proposes the following hypothesis:

H6: the engineering type may influence the positive impact of the cost objective on engineering harmony.

Risk management objective is based on activities such as communication, consultation, analysis, assessment, handling, monitoring and review of risks (Galvin, 2017; 
Isaac \& Edrei, 2016). Many projects show the characteristics of large scale, rapid construction speed, long period and complex operation, which make the project implementation of great risk and may cause serious social impact and economic loss. This requires the establishment of perfect engineering safety risk management laws, highlevel risk management principles. Human factors are the main factors that lead to the occurrence of risk, but also the key factors of the occurrence of engineering collusion and speculation. In risk assessment, dissonance of engineering can be easily caused by organizational influence, unsafe supervision, unsafe behavior and emergency influence (Xie \& Guo, 2017). At the same time, the manipulation of bidding is the main performance of engineering collusion (Reeves-Latour \& Morselli, 2016). High-level risk management can better achieve the coordination of risk management objective and customer objective, and control the risk of illegal bidding (Olechowski, Oehmen, Seering, \& Ben-Daya, 2016). Therefore, a good combination of risk composition, multidisciplinary nature, risk measurement and the development and use of risk management methods involved in risk management objective can promote engineering harmony by reducing the risk of engineering (Li, Yu, Jin, \& Liu, 2018). To sum up, this paper proposes the following hypothesis:

H7: the risk management objective has positive impact on achieving engineering harmony.

Risk management is systematic and complex. Due to differences in engineering types, it is also structural and dynamic, which runs through the life cycle of engineering management (Domingues, Baptista, \& Tato, 2017). Risk management should be as effective as possible and as realistic as possible because of the uncertainty reflected by the differences of engineering types. Therefore, investors with different preferences are attracted by different types of projects and decide to adopt risk preference, risk neutral or pure risk avoidance strategies according to the degree of risk return (Iqbal, Choudhry, Holschemacher, Ali, \& Tamošaitienè, 2015). Some scholars have studied the impact of engineering types on risk management. Through the survey of 200 project managers, this study found that the difference of engineering types significantly affected the difficulty level of risk management (Pimchangthong \& Boonjing, 2017). In many countries, engineering types also play a similar role. The project objective, product quality, delivery time and customer cost of the project management are relatively stable, and the risk avoidance, risk bearing or risk transfer strategy can be adopted according to the project type with high probability (Grennberg, 1993). Therefore, the impact of project type on engineering harmony focuses on control in multiple organizations, which plays an indirect regulatory role (Liu, Borman, \& Gao, 2014). To sum up, this paper proposes the following hypothesis:

H8: the engineering type may influence the positive impact of the risk management objective on engineering harmony.

\section{Methodology}

Meta-analysis is an important data statistical technique in empirical research (Hedges \& Olkin, 1985). The correlation between variables is verified by using meta-analysis software for analysis after coding the data of all independent samples in literatures related to the research topic (King, Dalton, Daily, \& Covin, 2004). Due to the differences in research objectives and methods selected by different literature when constructing and validating models, the conclusions drawn from the sample data in a certain literature cannot accurately reflect the relationship between variables (Hunter \& Schmidt, 2004; Cooper, Hedges, \& Valentine, 2009). Therefore, after sorting out samples from all literatures related to the research topic, the meta-analysis method and software can be used to convert all data into uniform weights and indicators, so as to avoid differences in selection of different literature samples and research objectives, and to verify the connection between variables more accurately. The meta-analysis is defined by the National (U.S.) Library of Medicine as "a quantitative method for combining results of independent studies (usually drawn from published literature) and synthesizing summaries and conclusions that can be used to assess therapeutic effectiveness, plan new studies, education, etc., with application mainly in the areas of research and medicine" (Gioacchino, 2005). For us, it is therefore equate "clinical studies" in medicine to "study problems domains" in management discipline (Card, 2012; Razo, Ramos, \& Occello, 2010).

In practical application, not only in the field of medicine, but also in the field of management, meta-analysis is widely used, because meta-analysis has considerable utility in clarifying management strategies and practical performance (Davis, Mengersen, Bennett, \& Mazerolle, 2014; Glass, McGaw, \& Smith, 1981; Mann, 1994; Petty, McGee, \& Cavender, 1984). Such as, specific application includes performance management (Bowen, Rostami, \& Steel, 2010; Springer, Stanne, \& Donovan, 1999), strategic management (Crook, Ketchen, Combs, \& Todd, 2008), innovation management (Büschgens, Bausch, \& Balkin, 2013; Weiss, Hoegl, \& Gibbert, 2017), organizational behaviour management (Atinc, Darrat, Fuller, \& Parker, 2010; Stajkovic \& Luthans, 2003), financial management (Dalton, Daily, Certo, \& Roengpitya, 2003), project management (Littau, Jyothi Jujagiri, \& Adlbrecht, 2010), construction management (Horman \& Kenley, 2005), etc. Moreover, there are two trends in the study of meta-analysis in management field: the rapid growth of literature number and the rapid expansion of the application field (Jiang, 2012). The metaanalysis method is applicable to the research of engineering management problems. For example, the control index for construction time waste needs to be structured and replicable, which can be effectively done by meta-analysis (Horman \& Kenley, 2005). The meta-analysis method has been verified to be applicable to study the whole engineering decision-making process from planning to construc- 
tion, involving in building informatization, transportation engineering, architecture and construction technology, etc. (Abdal Noor, 2018; Zhao, 2017).

Scholars at home and abroad have extensively discussed the trade-offs of quality, duration, cost and risk in the process of realizing engineering harmony through theoretical and empirical research (Amusan, Afolabi, Ojelabi, Omuh, \& Okagbue, 2018; Idiake et al., 2015), but the specific mechanism of influence is still controversial. The controversies include the standards for achieving engineering harmony (Musa et al., 2015). The clients of the terminal believe that engineering harmony originates from the achievement of goals such as quality, duration, cost and risk (Pinto \& Slevin, 2013); managers believe that it is the process of achieving the four goals (Wilson, 2015), and stakeholders believe that all four goals need to meet their expectations (Toor \& Ogunlana, 2009). A problem has its constituent properties, each of which must be identified by text or abstract analysis and then linked to at least one of the domains to which it belongs. Meta-analysis using probabilistic representation to describe problems based on Bayesian programming is an accurate choice (Razo et al., 2010). By analyzing the set of grouped results, the most accurate results are found to be suitable for a given problem (Hunter \& Schmidt, 2004). Therefore, the controversy about the specific influence mechanisms makes this study suitable to use the meta-analysis method to deal with.

\section{Literature collection and analysis}

\subsection{Literature collection}

This study mainly collects the empirical literatures on the relationship among quality, duration, cost, risk, and engineering harmony. By combining key words related to engineering harmony (such as project success, project performance, project satisfaction, etc.) and major factors of the dimension of "physical fitness" (such as quality, duration, cost and risk), the database such as EBSCOhost, Elsevier Science Direct, Springerlink, etc. were consulted. In addition, in order to reduce publication deviation, unpublished studies were searched through network search software such as SSRN database, Baidu academy and Baidu Wenku, and a total of 29 studies were conducted.

In the process of screening relevant literature, this study mainly adopts the following standards. First, focus on construction or engineering, including housing, transportation, energy and infrastructure-related projects, not corporate projects. Second, independent samples must be used in relevant studies. In literature coding, if the same data set is used more than once but contains different variables, the corresponding data is calculated respectively. An average is used to represent it when a variable contains multiple dimensions. Under this standard, there were 29 preliminary studies, i.e., 31 independent samples, as shown in Table 1.

\subsection{Literature coding}

\subsubsection{Variable selection}

Whether the engineering is harmonious or not is difficult to be measured by a certain standard. Al-Bahar and Crandall (1990) suggest judging whether the engineering is harmonious through the comprehensive performance of the engineering. Some scholars believe that stakeholders' satisfaction with the engineering is an important indicator of engineering harmony (Hwang \& Ng, 2016). In addition, most scholars believe that the successful completion of the engineering in the aspects of people, things, objects and environment can be reflected as engineering harmony. On the whole, the results of previous studies have been summarized in the existing literature, and it is believed that the basic standards of engineering harmony in the physical fitness dimension can be measured by factors such as quality, duration, cost and risk (Lim \& Mohamed, 1999). That is, whether the project is harmonious or not, comes from the comprehensive impact of quality, duration, cost and risk.

\subsubsection{Meta-analysis process}

According to the results of literature coding, namely the correlation coefficient in the Pearson correlation matrix between variables, the effect value is calculated. If there are multiple correlation coefficients between variables in a certain study, the average value is calculated. The estimated value of measurement error is adjusted to obtain the corrected effect value.

Second, publication deviation is checked. Publication deviation refers to the selectivity deviation caused by the journal publishing preference of significantly different results. And papers that have unverified research hypotheses or have insignificant results will not be published. The check of publication deviation is generally expressed with fail-safe Number (fs N), which is the minimum to make existing conclusions less significant. The higher the value, the less likely the deviation is. When fs $\mathrm{N}$ exceeds the Rosenthal standard (i.e. $5^{\star}$ number of studies +10 ), there is no significant publication deviation. In the process of research, if potential regulatory variables need to be identified, homogeneity test shall be conducted, that is, $\mathrm{Q}$ test shall be adopted to confirm whether the difference coefficient is significant. The emphasis of the meta-analysis method is the accuracy of sampling, and the weight is given by the "sample size" in the original independent sample. The utility value data in table 1 can be automatically unified and standardized converted by "Comprehensive Meta Analysis" software, and there is no need to carry out weight design again.

\section{Results of the study}

\subsection{Homogeneity test}

The homogeneity test is used to determine whether there is homogeneity or heterogeneity among different research 
Table 1. Basic data of original research

\begin{tabular}{|c|c|c|c|c|c|c|c|c|c|}
\hline Original research & $\begin{array}{l}\text { Sample } \\
\text { number }\end{array}$ & $\begin{array}{l}\text { Countries } \\
\text { and Areas }\end{array}$ & $\begin{array}{l}\text { Engineering } \\
\text { types }\end{array}$ & $\begin{array}{l}\text { Bachelor } \\
\text { and above }\end{array}$ & \begin{tabular}{|c|} 
Work \\
experience
\end{tabular} & Quality & Duration & Cost & Risk \\
\hline $\begin{array}{l}\text { García, Valles, } \\
\text { Sánchez, Noriega, and } \\
\text { Dominguez (2017) }\end{array}$ & 256 & Mexico & Road & & & 0.428 & 0.398 & 0.497 & 0.438 \\
\hline $\begin{array}{l}\text { Semab, Khan, and Shah } \\
\text { (2017) }\end{array}$ & 264 & Pakistan & $\begin{array}{l}\text { Roads/Govt } \\
\text { Buildings/Houses }\end{array}$ & & $60 \%$ & & -0.644 & & \\
\hline $\begin{array}{l}\text { Yang, Chen, and Huang } \\
\text { (2013) }\end{array}$ & 213 & Taiwan & $\begin{array}{l}\text { Construction } \\
\text { industry }\end{array}$ & $53.06 \%$ & $33.80 \%$ & 0.56 & 0.92 & 0.87 & \\
\hline Chandra (2015) & 180 & Surabaya & $\begin{array}{l}\text { Construction } \\
\text { industry }\end{array}$ & & $15 \%$ & 0.873 & 0.804 & 0.876 & 0.137 \\
\hline $\begin{array}{l}\text { Chandra, Indarto, } \\
\text { Wiguna, and Kaming } \\
(2012)\end{array}$ & 204 & East Java & $\begin{array}{l}\text { Construction } \\
\text { industry }\end{array}$ & & & 0.71 & 0.63 & 0.58 & \\
\hline Badewi (2016) & 300 & $\begin{array}{l}\text { around the } \\
\text { world }\end{array}$ & House & & & & 0.81 & 0.85 & \\
\hline Musa et al. (2015) & 276 & Nigeria & Houses & $80.80 \%$ & $64.10 \%$ & 0.62 & 0.70 & 0.61 & \\
\hline $\begin{array}{l}\text { Nguyen and } \\
\text { Hadikusumo (2017) }\end{array}$ & 586 & Thailand & Energy & & & 0.53 & 0.83 & 0.56 & \\
\hline Hasan (2017) & 376 & China & House & & & & & 0.35 & 0.62 \\
\hline $\begin{array}{l}\text { Sun, Shen, and Fan } \\
(2012)\end{array}$ & 136 & China & PPP & & & 0.97 & -0.53 & -0.55 & 0.67 \\
\hline $\mathrm{Hu}$ and Zhang (2016) & 142 & China & Road & & & 1 & -0.58 & -0.45 & 0.94 \\
\hline $\begin{array}{l}\text { Sambasivan, Deepak, } \\
\text { Salim, and Ponniah } \\
(2017)\end{array}$ & 308 & Tanzania & Construction & & $46 \%$ & & & 0.59 & \\
\hline Sambasivan et al. (2017) & 308 & Tanzania & Construction & & $46 \%$ & & & & 0.497 \\
\hline $\begin{array}{l}\text { Jin, Shen, and Wang } \\
(2018)\end{array}$ & 57 & $\begin{array}{l}\text { North } \\
\text { America }\end{array}$ & $\begin{array}{l}\text { Industrial } \\
\text { construction }\end{array}$ & & & -0.272 & & & \\
\hline Liu et al. (2017) & 150 & China & Construction & & $11.34 \%$ & & & & 0.256 \\
\hline $\begin{array}{l}\text { Ikediashi and } \\
\text { Ogwueleka (2016) }\end{array}$ & 240 & Nigeria & Construction & & $80 \%$ & 0.526 & 0.307 & 0.441 & \\
\hline Amusan et al. (2018) & 70 & Nigeria & Construction & & $42.80 \%$ & 0.576 & 0.796 & 0.656 & \\
\hline $\begin{array}{l}\text { Doloi, Iyer, and } \\
\text { Sawhney (2011) }\end{array}$ & 97 & Australia & Construction & & $59.30 \%$ & 0.46 & & & \\
\hline $\begin{array}{l}\text { Golchin Rad and Kim } \\
\text { (2018) }\end{array}$ & 152 & Iran & Construction & & & 0.73 & 0.83 & & \\
\hline Daihu (2015) & 443 & China & Construction & $90 \%$ & $9.70 \%$ & 0.16 & 0.15 & & \\
\hline Liu (2016) & 63 & China & & & & & & & -0.5 \\
\hline Zhang et al. (2018) & 121 & China & & & & & & & -0.31 \\
\hline Teller and Kock (2013) & 176 & Germany & $\begin{array}{l}\text { Energy and } \\
\text { infrastructure }\end{array}$ & & & & & & -0.15 \\
\hline $\begin{array}{l}\text { Suprapto, Bakker, Mooi, } \\
\text { and Hertogh }(2016)\end{array}$ & 119 & Netherlands & $\begin{array}{l}\text { Engineering and } \\
\text { construction }\end{array}$ & & & 0.465 & & & \\
\hline $\begin{array}{l}\text { Sarigiannidis and } \\
\text { Chatzoglou (2014) }\end{array}$ & 112 & Greece & & & & -0.293 & & & \\
\hline $\begin{array}{l}\text { D. Y. Kim, H. Kim, } \\
\text { Han, and Park (2009) }\end{array}$ & 126 & & Construction & & & 0.417 & & 0.457 & \\
\hline $\begin{array}{l}\text { Haq, Liang, } \mathrm{Gu} \text {, and } \mathrm{Ma} \\
(2016)\end{array}$ & 354 & Pakistan & & & & 0.173 & & & 0.089 \\
\hline $\begin{array}{l}\text { Nam, Duc, and Duy } \\
(2016)\end{array}$ & 212 & Vietnam & Railway & & & & & & -0.028 \\
\hline $\begin{array}{l}\text { Nitithamyong, } \\
\text { Skibniewski, and Clark } \\
(2007)\end{array}$ & 82 & $\begin{array}{l}\text { United } \\
\text { States }\end{array}$ & $\begin{array}{l}\text { Build/ } \\
\text { Construction }\end{array}$ & & & 0.629 & 0.792 & 0.773 & 0.625 \\
\hline
\end{tabular}


tissues, and to determine whether the correlation coefficient is analyzed by using the fixed effect model or random effect model. In this study, the homogeneity test results of effect values for quality, duration, cost and risk affecting engineering harmony are shown in Table 2 . The $\mathrm{Q}$ values are $720.531,1655.500,746.045$ and 581.086 , respectively, and all $\mathrm{p}$ values are less than 0.001 , indicating that the effect values are heterogeneous. I-squared is $97.641,99.154$, 98.123 and 97.935 , respectively, both greater than $75 \%$, indicating that the effect value have high heterogeneity. From the above analysis results, it can be concluded that the random effect model should be adopted in this study. In addition, the Tau-squared value in Table 2 also shows that the total variation has inter-group error.

\subsection{Publication deviation test}

In order to avoid publication deviation in selected literatures and to affect the evaluation of effect values, this study adopted multiple methods such as safety loss coefficients, rank correlation test, regression intercept, clipping method (see Table 3) and funnel plot (see Figures 1-4) to measure publication deviation. The data in Table 3 shows that the safety loss coefficients are 5546, 4487, 4977 and 1051 respectively, both greater than $5 \mathrm{~K}+10$ (the $\mathrm{K}$ values of quality, duration, cost and risk in this study are 19, 15, 15 and 11 respectively). In addition, from the perspective of Tau value of the rank correlation test and regression intercept, $\mathrm{p}$ value is all greater than 0.1 , which is not significant, indicating that there is no publication deviation in the effect value of quality, duration, cost and risk affecting engineering harmony. Figures 1-4 funnel plot shows that most of the relevant studies are located at the top of funnel plot, and are distributed relatively uniformly in the peripheral region of the intermediate value, which also indicates that there is less possibility of publication deviation of effect values.

\subsection{Total effect test}

As shown in Table 4, there are 17, 14, 14 and 11 effect values for the relationship between quality, duration, cost and risk and engineering harmony, respectively. The total sample sizes are $3845,3544,3495$ and 2556, and the correlation coefficients are $0.540(\mathrm{p}<0.05), 0.528(\mathrm{p}<$ $0.05), 0.548(\mathrm{p}<0.05)$, and $0.332(\mathrm{p}<0.05)$, respectively, which are significant. According to Lipsey and Wilson (2001), when the absolute value of correlation coefficient is greater than 0.1 , it is moderately correlated, and when

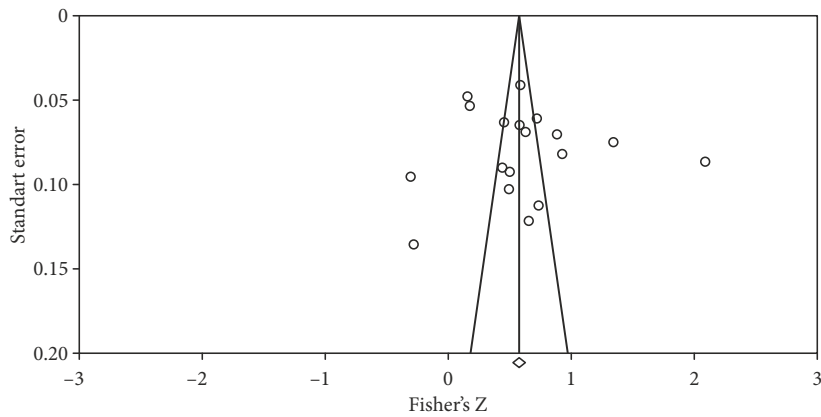

Figure 1. Funnel plot of quality-engineering harmony effect value

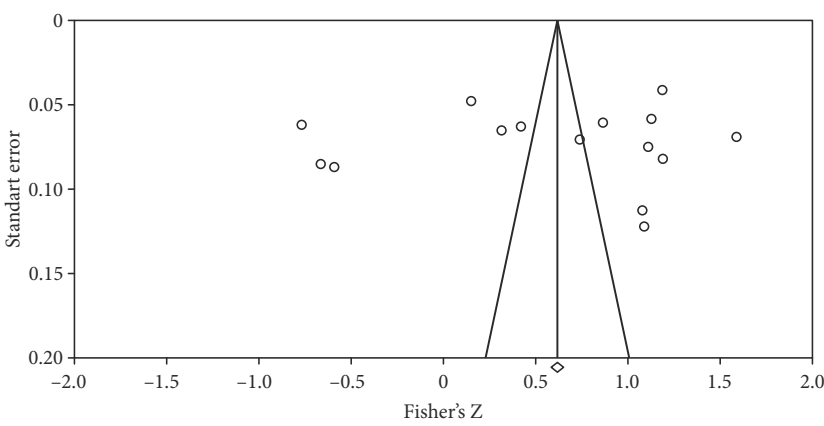

Figure 2. Funnel plot of duration-engineering harmony effect value

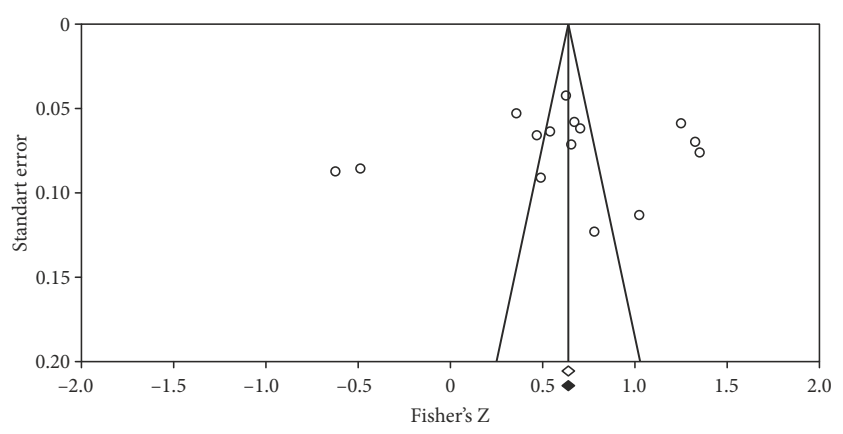

Figure 3. Funnel plot of cost-engineering harmony effect value

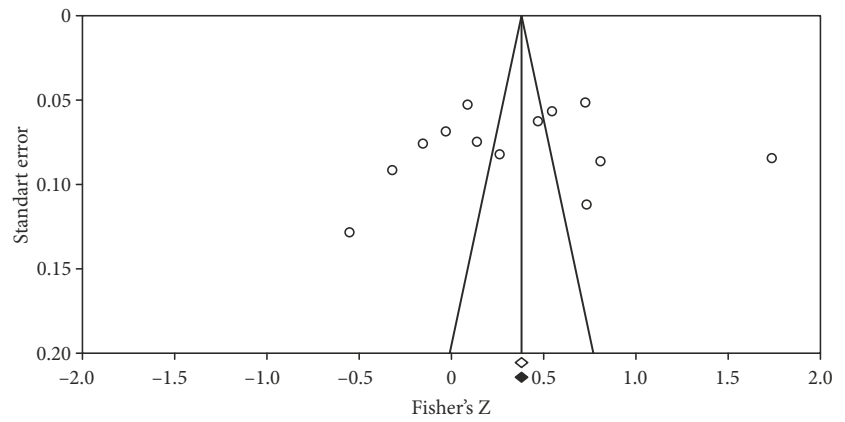

Figure 4. Funnel plot of risk-engineering harmony effect value

Table 2. The homogeneity test results of effect values ( $Q$ statistics)

\begin{tabular}{|c|c|c|c|c|c|c|c|c|c|}
\hline \multirow{2}{*}{$\begin{array}{c}\text { Random effect } \\
\text { model }\end{array}$} & \multirow{2}{*}{$\begin{array}{l}\text { Number } \\
\text { of samples }\end{array}$} & \multicolumn{4}{|c|}{ Heterogeneity } & \multicolumn{4}{|c|}{ Tau-squared } \\
\hline & & Q-value & $\mathrm{Df}(\mathrm{Q})$ & P-value & I-squared & Tau-squared & SE & Variance & Tau \\
\hline Quality & 19 & 720.531 & 17 & 0.000 & 97.641 & 0.210 & 0.087 & 0.008 & 0.458 \\
\hline Duration & 15 & 1655.500 & 14 & 0.000 & 99.154 & 0.514 & 0.221 & 0.049 & 0.717 \\
\hline Cost & 15 & 746.045 & 14 & 0.000 & 98.123 & 0.232 & 0.100 & 0.010 & 0.482 \\
\hline Risk & 13 & 581.086 & 12 & 0.000 & 97.935 & 0.250 & 0.115 & 0.013 & 0.500 \\
\hline
\end{tabular}


Table 3. The test value of publication deviation

\begin{tabular}{|c|c|c|c|c|c|}
\hline \multirow{2}{*}{$\begin{array}{c}\text { Safety loss } \\
\text { coefficients (Nfs) }\end{array}$} & $\begin{array}{c}\text { Rank correlation } \\
\text { test (Tau) }\end{array}$ & Regression intercept & \multicolumn{3}{|c|}{ Trim and fill } \\
\cline { 4 - 6 } & & & Observations & Adjusted value & Variation value \\
\hline 5546 & $0.059(\mathrm{p}=0.762)$ & $3.094(\mathrm{p}=0.275)$ & 0.521 & 0.521 & 0 \\
\hline 4487 & $-0.124(\mathrm{p}=0.276)$ & $-4.407(\mathrm{p}=0.347)$ & 0.548 & 0.648 & 0 \\
\hline 4977 & $-0.029(\mathrm{p}=0.461)$ & $-3.059(\mathrm{p}=0.342)$ & 0.568 & 0.568 & 0 \\
\hline 1051 & $-0.179(\mathrm{p}=0.214)$ & $-3.214(\mathrm{p}=0.350)$ & 0.361 & 0.361 & 0 \\
\hline
\end{tabular}

Table 4. Random model analysis of the relationship between quality, duration, cost, risk and engineering harmony

\begin{tabular}{|c|c|c|c|c|c|c|c|}
\hline \multirow{2}{*}{$\begin{array}{l}\text { Independent } \\
\text { variable }\end{array}$} & \multirow{2}{*}{$\begin{array}{l}\text { Number of } \\
\text { studies }\end{array}$} & \multirow{2}{*}{$\begin{array}{l}\text { Sample } \\
\text { capacity }\end{array}$} & \multicolumn{3}{|c|}{ Effect value and $95 \%$ confidence interval } & \multicolumn{2}{|c|}{ Two-tailed test } \\
\hline & & & Point estimation & Lower limit & Upper limit & Z-value & P-value \\
\hline Quality & 17 & 3845 & 0.540 & 0.371 & 0.675 & 5.506 & 0.000 \\
\hline Duration & 14 & 3544 & 0.528 & 0.221 & 0.740 & 3.174 & 0.002 \\
\hline Cost & 14 & 3495 & 0.548 & 0.352 & 0.697 & 4.879 & 0.000 \\
\hline Risk & 11 & 2556 & 0.332 & 0.070 & 0.552 & 2.456 & 0.014 \\
\hline
\end{tabular}

Table 5. Regulatory effect of engineering type on engineering harmony affected by quality, duration, cost and risk

\begin{tabular}{|l|c|c|c|c|c|c|}
\hline Independent variable & $\mathrm{K}$ & Sample capacity & Average effect value & 95\% Confidence interval & Q-value & P-value \\
\hline Quality & 17 & 3845 & 0.117 & $-0.241 \sim 0.447$ & 7.534 & 0.023 \\
\hline Duration & 14 & 3544 & 0.650 & $0.083 \sim 0.899$ & 0.254 & 0.881 \\
\hline Cost & 14 & 3495 & 0.717 & $0.202 \sim 0.921$ & 1.744 & 0.418 \\
\hline Risk & 11 & 2556 & -0.066 & $-0.426 \sim 0.312$ & 12.321 & 0.002 \\
\hline
\end{tabular}

it is greater than 0.4 , it is highly correlated. It can be seen that the relationship between quality, duration, cost, risk and engineering harmony is above moderate correlation. The $95 \%$ confidence intervals are $[0.371,0.675],[0.221$, $0.740],[0.352,0.697],[0.070,0.552]$. Thus, hypotheses 1 , 3,5 and 7 all pass.

\subsection{Regulatory effect of engineering type}

The engineering included in the meta-analysis are divided into single type and compound type. The data in Table 5 shows that there is no significant difference in the impact of duration and cost on engineering harmony under the two types $(\mathrm{Q}$-value $=0.254, \mathrm{p}>0.1 ; \mathrm{Q}$-value $=1.744$, $\mathrm{p}>0.1$ ), while there is significant difference in the impact of quality and risk on engineering harmony (Q-value = 7.534, $\mathrm{p}<0.1$; Q-value $=12.321, \mathrm{p}<0.1)$. It is shown that the engineering type has no regulatory effect on the impact of the duration and cost on engineering harmony, and has regulatory effect on the quality and risk. So hypothesis 4 and hypothesis 6 fail, and hypothesis 2 and hypothesis 8 pass.

\section{Research conclusions and management implications}

(1) Quality objective, engineering type and engineering harmony

The hypothesis 1 and hypothesis 2 are verified in this study, that is to say, the quality objective has positive im- pact on the realization of engineering harmony. By actively carrying out quality management, engineering harmony can be effectively promoted. This conclusion is consistent with the views of scholars such as Kiew, Ismail, and Yusof (2016) and Sullivan (2011). Engineering construction is a people-oriented production activity. The technical level, organizational capacity, ideological level, psychological behavior, consciousness level and judgment ability of engineering organizers will affect the project quality directly, and internal harmony can be achieved through personnel restriction by engineering quality management (Kiew et al., 2016). Whether the engineering materials are up to standard, whether the engineering technology is advanced, and whether the engineering operation is correct will affect the realization of the engineering quality directly. Carrying out the engineering quality management can improve the structural safety and the personal safety of users, and also directly affect the economic return of investors. Engineering quality management can effectively improve the progress, quality and economic benefits of the engineering, improve customer satisfaction, and enhance the harmonious relationship between the proprietor, contractor and builder (Sullivan, 2011). Hypothesis 2: The engineering type effect of positive impact of quality objective on engineering harmony has been verified, which is consistent with the views of scholars such as Lines, Sullivan, Smithwick, and Mischung (2015). As the engineering type involves multiple fields such as highway, railway and housing construction, different types of engineering 
have different degrees of novelty, complexity and technical uncertainty, as well as different methods and difficulties of project quality management (Lines et al., 2015). In the process of engineering management, it is particularly important to take quality as the objective to control the engineering stage, which needs to be treated separately according to different engineering types. As a result, the regulation effect of engineering type is established on quality objective on engineering harmony.

The research shows that, in the construction practice and academic research of engineering projects, the quality target is affected by the common influence of personnel, material and environmental factors, which has indirect influence on the engineering harmony. Therefore, in the process of engineering management, it is necessary to strengthen the management resource input. To achieve engineering harmony, construction personnel training and education should be strengthened to improve personnel quality management level, quality assurance system should be established to standardize material quality management, and environmental change features and limitations should be mastered to break through environmental quality management (Mao \& Xu, 2011). By improving the engineering organization and management system, setting up project quality supervision standards, and efficiently implementing quality control methods and measures, the project quality management level can be improved. Furthermore, it can promote the harmonious development between project personnel management, project construction and natural environment effectively (Rao, Viswanadhan, \& Raghunandana, 2015).

\section{(2) Duration objective, engineering type and engineering harmony}

Hypothesis 3 is verified, while hypothesis 4 is not verified in this study. That is to say, the duration objective has a positive impact on the realization of engineering harmony. This result verifies the research of FernandezViagas \& Framinan (2015), Russell et al. (2015) and other scholars. The project involves multiple interests, including the owner, constructer and supervisor, which not only requires construction quality assurance of the project construction, but also requires timely completion and guarantee of construction period. In fact, in the process of engineering construction, due to the influence of various factors such as construction plan, technical plan and personnel allocation, the actual duration cannot be completely consistent with the planned duration, and there is a certain error (Aliverdi, Naeni, \& Salehipour, 2013). In the long run, the construction delay caused by the improper management of the construction period will affect the reputation and image of the constructer and the owner, as well as create conflict among stakeholders. Thus it can be seen that the high efficiency and high quality duration objective can achieve engineering harmony effectively. Hypothesis 4: The engineering type effect of positive impact of duration objective on engineering harmony has not been verified, which is contrary to the views of scholars such as Wang, Yu, and Chan (2012). There are differences in the environment, technical standards, personnel arrangement and construction plans of different types of engineering projects, so there are differences in the planned construction period (Khamooshi \& Cioffi, 2013; Thoedtida, 2014). Although different types of projects have different risks, different quality and standards, schedule management is necessary and indispensable for stakeholders. To some extent, the difference of engineering type will affect the standard of construction period management. However, there is no significant difference in the process, purpose and process control of construction period management. Therefore, engineering type is not the factor that affects the engineering harmony and regulates construction period management.

For both theoretical and practical aspects, the schedule management of engineering is an important link of engineering management, which affects the achievement of engineering harmony indirectly. Although there are differences in the engineering types, the realization process of duration target is consistent, and the standards of duration management are much the same. Real-time tracking and feedback of project progress information is required, and an emergency response team should be established to give timely feedback and quickly form a response plan in case of emergency. Therefore, the construction period management not only needs to be prepared in advance to ensure that the period is guaranteed under the premise of buffer zone setting, but also needs to adapt to the dynamic changes of the environment to achieve the harmony of the internal management and the external environment.

\section{(3) Cost objective, engineering type and engineering har- mony}

Hypothesis 5 is verified, while hypothesis 6 is not verified in this study, that is, the cost objective has positive impact on the realization of engineering harmony. In previous studies Ameh, Soyingbe, and Odusami (2010) and other scholars believed that engineering can improve engineering performance by pursuing the optimization of cost. The cost objective is a comprehensive index to reflect the engineering harmony. Especially in the market economy, construction enterprise is regarded as independent competitor, its operation and management objective is to coordinate various internal economic relations with the lowest cost continuously, so as to achieve the engineering harmony. The cost objective management is a strategic cost control, on the premise of ensuring the engineering quality, through satisfaction design of quantitative cost management method and its interaction and coupling, which can reduce energy consumption, improve labor productivity, coordinate the economic interests of stakeholders, promote the continuous improvement of project management, and achieve the minimum cost and maximum engineering harmony finally. Hypothesis 6: The engineering type effect of positive impact of cost objective on engineering harmony has not been verified, which is contrary to the research of scholars such as Safapour, Ker- 
manshachi, Habibi, and Shane (2018). Although different types of engineering have different degrees of complexity, since cost management is a comprehensive dynamic management process, there are both material production activities and non-material production activities related to the engineering itself. Moreover, due to the great uncertainty of the internal conditions and objective environment, the realization of the cost objective depends on the feasibility of the investment planning and the effectiveness of the target control largely. The impact of the engineering type is limited, so the engineering type is not an element of impact of cost objective on engineering harmony.

The conclusion has some implications for the realization of engineering harmony management. Engineering projects are characterized by multiple key links and complex interference factors. Controlling project cost and realizing management harmony are always the goals of engineering management. Combining the cost objective with the engineering management, we will build a modern cost management system based on engineering harmony, promote the cost management to be transparent and the department responsibility to be specific, and allow more enterprise employees to be stakeholders of the cost objective, so as to mobilize their enthusiasm and creativity.

\section{(4) Risk management objective, engineering type and engi- neering harmony}

The hypothesis 7 and hypothesis 8 are verified in this study, that is, risk management objective has a positive impact on the realization of engineering harmony, and the engineering type has a regulatory effect on the engineering harmony to the positive effect of risk management objective. The conclusion is in line with the views of scholars such as M. Arashpour, Abbasi, M. Arashpour, Hosseini, and Yang (2017), Hwang and Ng (2016), Xia, Zou, Griffin, Wang, and Zhong (2018). The contradiction between risk management objective and stakeholders' demands is particularly prominent in the construction project, and the failure of the project is also common (Mok, Shen, \& Yang, 2015). To some extent, good control of risk management objective can meet the demands of stakeholders directly or indirectly, thus engineering harmony can be achieved (Xia et al., 2018). In addition, the differences of engineering types have a great influence on the degree of implementing risk management and a certain degree of adjustment to the realization of engineering harmony (Pimchangthong \& Boonjing, 2017). Engineering projects can be classified into general projects and major projects according to their importance. Compared with general projects, major projects involve more capital, complex processes and high safety requirements, so both capital risk and construction risk are obvious, and the probability of project collusion is also higher. The focus of each project is different, and the required risk management objective is also different. Moreover, the differences of engineering types also indirectly affect the risk management mode, including risk transfer, risk avoidance, risk taking, risk sharing and other strategies.
Both in academic research and in practical operation, risk management and stakeholder management are often attached with negative views (Wang, Xia, Zhang, Wu, \& Liu, 2017), that is, risk discovery and stakeholder conflict are not conducive to promoting project construction. This study reveals the relationship between risk management, engineering types and engineering harmony. It is believed that if engineering harmony is to be achieved, construction enterprises should pay attention to risk management, and different engineering types should be considered in the process of risk management. Targeted risk control should be conducted according to engineering types. The purpose of risk management is to increase the possibility and impact of positive events and reduce negative events in the engineering (Arashpour et al., 2017). The realization of engineering harmony not only requires a reasonable and efficient risk management model, but also needs to analyze the relationship network of stakeholders deeply. According to the differences in the interest demands of stakeholders such as the government, shareholders and creditors, a differentiated and targeted risk warning, risk sharing, risk transfer and risk control strategy is formulated.

\section{Acknowledgements}

Professor Huatao Peng from School of Management, Wuhan University of technology, gave his valuable suggestions on this research. The authors would like to express their gratitude to him.

\section{Funding}

There is no funding supporting the research.

\section{Author contributions}

Qiankun Wang conceived the study and supervised the whole research process. Weiwei Zuo was responsible for data analysis and interpretation as well as wrote the manuscript. Qianyao Li was responsible for data collection and proofreading of the manuscript.

\section{Disclosure statement}

There is no competing financial, professional, or personal interest from other parties.

\section{References}

Abdal Noor, B. (2018). Review of BIM literature in construction industry and transportation: meta-analysis. Construction Innovation, 18(4), 433-452.

https://doi.org/10.1108/CI-05-2017-0040

Al-Bahar, J. F., \& Crandall, K. C. (1990). Systematic risk management approach for construction projects. Journal of Construction Engineering and Management, 116(3), 533-546.

https://doi.org/10.1061/(ASCE)0733-9364(1990)116:3(533) 
Alger, P. L. (2013). Engineering and quality control. Electrical Engineering, 66(1), 16-19.

https://doi.org/10.1109/EE.1947.6443323

Aliverdi, R., Naeni, L. M., \& Salehipour, A. (2013). Monitoring project duration and cost in a construction project by applying statistical quality control charts. International Journal of Project Management, 31(3), 411-423.

https://doi.org/10.1016/j.ijproman.2012.08.005

Ameh, O. J., Soyingbe, A. A., \& Odusami, K. T. (2010). Significant factors causing cost overruns in telecommunication projects in Nigeria. Journal of Construction in Developing Countries, 15(2), 49-67.

Amusan, L. M., Afolabi, A., Ojelabi, R., Omuh, I., \& Okagbue, H. I. (2018). Data exploration on factors that influences construction cost and time performance on construction project sites. Data in Brief, 17, 1320-1325.

https://doi.org/10.1016/j.dib.2018.02.035

Arashpour, M., Abbasi, B., Arashpour, M., Hosseini, M. R., \& Yang, R. (2017). Integrated management of on-site, coordination and off-site uncertainty: Theorizing risk analysis within a hybrid project setting. International Journal of Project Management, 35(4), 647-655.

https://doi.org/10.1016/j.ijproman.2017.02.016

Assaf, S. A., \& Al-Hejji, S. (2006). Causes of delay in large construction projects. International Journal of Project Management, 24(4), 349-357.

https://doi.org/10.1016/j.ijproman.2005.11.010

Atinc, G., Darrat, M., Fuller, B., \& Parker, B. W. (2010). Perceptions of organizational politics: A meta-analysis of theoretical antecedents. Journal of Managerial Issues, 22(4), 494-513.

Azaron, A., Katagiri, H., \& Sakawa, M. (2007). Time-cost tradeoff via optimal control theory in Markov PERT networks. Annals of Operations Research, 150(1), 47-64. https://doi.org/10.1007/s10479-006-0149-x

Badewi, A. (2016). The impact of project management (PM) and benefits management (BM) practices on project success: Towards developing a project benefits governance framework. International Journal of Project Management, 34(4), 761-778. https://doi.org/10.1016/j.ijproman.2015.05.005

Bowen, F. E., Rostami, M., \& Steel, P. (2010). Timing is everything: A meta-analysis of the relationships between organizational performance and innovation. Journal of Business Research, 63(11), 1179-1185.

https://doi.org/10.1016/j.jbusres.2009.10.014

Büschgens, T., Bausch, A., \& Balkin, D. B. (2013). Organizational culture and innovation: A meta-analytic review. Journal of Product Innovation Management, 30(4), 763-781. https://doi.org/10.1111/jpim.12021

Card, N. A. (2012). Applied meta-analysis for social science research. New York, NY, US: Guilford Press.

Chandra, H. P. (2015). Structural equation model for investigating risk factors affecting project success in Surabaya. Procedia Engineering, 125, 53-59.

https://doi.org/10.1016/j.proeng.2015.11.009

Chandra, H. P., Indarto, Wiguna, P. A. I., \& Kaming, P. F. (2012). Model of stakeholder influence on project success, an important finding from construction project in East Java. International Journal of Academic Research, 4(2), 41-45.

Chen, Q., Jin, Z., Xia, B., Wu, P., \& Skitmore, M. (2016). Time and cost performance of design-build projects. Journal of Construction Engineering and Management, 142(2), 414-415. https://doi.org/10.1061/(ASCE)CO.1943-7862.0001056
Chou, J. S. (2011). Cost simulation in an item-based project involving construction engineering and management. International Journal of Project Management, 29(6), 706-717.

https://doi.org/10.1016/j.ijproman.2010.07.010

Crook, T. R., Ketchen, D. J., Combs, J. G., \& Todd, S. Y. (2008). Strategic resources and performance: A meta-analysis. Strategic Management Journal, 29(11), 1141-1154.

https://doi.org/10.1002/smj.703

Daihu, C. (2015). Research on impact of risk management ability of project on contextual performance (Master's thesis). Dalian University of Technology.

Dalton, D. R., Daily, C. M., Certo, S. T., \& Roengpitya, R. (2003). Meta-analyses of financial performance and equity: Fusion or confusion? Academy of Management Journal, 46(1), 13-26. https://doi.org/10.2307/30040673

Davis, J., Mengersen, K., Bennett, S., \& Mazerolle, L. (2014). Viewing systematic reviews and meta-analysis in social research through different lenses. Springerplus, 3, 511. https://doi.org/10.1186/2193-1801-3-511

Deshpande, A. M., Siddhalingeshwar, I. G., \& Ekabote, N. (2016). Implementation of advanced product quality planning in engineering project. Journal of Biotechnology, 185, S7. https://doi.org/10.16920/jeet/2016/v0i0/85705

Doloi, H., Iyer, K. C., \& Sawhney, A. (2011). Structural equation model for assessing impacts of contractor's performance on project success. International Journal of Project Management, 29(6), 687-695.

https://doi.org/10.1016/j.ijproman.2010.05.007

Domingues, M. S. Q., Baptista, A. L. F., \& Tato, D. M. (2017). Engineering complex systems applied to risk management in the mining industry. International Journal of Mining Science and Technology, 27(4), 611-616. https://doi.org/10.1016/j.ijmst.2017.05.007

Feng, H., Wei, J., \& Zhang, G. (2015). Earned value method in the application of the project schedule and cost management of highway construction. International Journal of Science, 2(7), 21-24.

Fernandez-Viagas, V., \& Framinan, J. M. (2014). Integrated project scheduling and staff assignment with controllable processing times. The Scientific World Journal, 924120.

https://doi.org/10.1155/2014/924120

Fernandez-Viagas, V., \& Framinan, J. M. (2015). Controllable processing times in project and production management: Analysing the trade-off between processing times and the amount of resources. Mathematical Problems in Engineering, 826318. https://doi.org/10.1155/2015/826318

Foy, T. D. (2013). Quality control as a management tool: Organization of quality control as a management tool. Electrical Engineering, 66(5), 483-486.

https://doi.org/10.1109/EE.1947.6443521

Frank, M., Sadeh, A., \& Ashkenasi, S. (2011). The relationship among systems engineers' capacity for engineering systems thinking, project types, and project success. Project Management Journal, 42(5), 31-41. https://doi.org/10.1002/pmj.20252

Fu, F., \& Zhang, T. (2016). A new model for solving time-costquality trade-off problems in construction. Plos One, 11(12), e0167142. https://doi.org/10.1371/journal.pone.0167142

Galvin, J. (2017). Critical role of risk management in ground engineering and opportunities for improvement. Journal of China University of Mining \& Technology, 27(5), 725-731. https://doi.org/10.1016/j.ijmst.2017.07.005

García, H., Valles, A., Sánchez, J., Noriega, S., \& Dominguez, G. (2017). Statistical equation modeling analysis for industrial 
projects, designing for critical factors and latent variables: quality, cost, time, and success. The International Journal of Advanced Manufacturing Technology, 88(1), 767-779.

https://doi.org/10.1007/s00170-016-8675-4

Garwood, D. A., \& Poole, A. H. (2018). Project management as information management in interdisciplinary research: "Lots of different pieces working together". International Journal of Information Management, 41(4), 14-22.

https://doi.org/10.1016/j.ijinfomgt.2018.03.002

Gioacchino, L. (2005). Meta-analysis in medical research: The handbook for the understanding and practice of meta-analysis. Oxford: Blackwell Publishing.

Glass, G. V., McGaw, B., \& Smith, M. L. (1981). Meta-analysis in social research. Beverly Hills, CA: Sage.

Golchin Rad, K., \& Kim, S.-Y. (2018). Factors affecting construction labor productivity: Iran case study. Iranian Journal of Science and Technology, Transactions of Civil Engineering, 42(2), 165-180. https://doi.org/10.1007/s40996-018-0095-2

Grennberg, T. (1993). Project types in building and construction. International Journal of Project Management, 11(2), 68-71. https://doi.org/10.1016/0263-7863(93)90012-C

Haq, S. U., Liang, C., Gu, D., \& Ma, Y. (2016). Understanding the determinantsof project performance: Empirical evidencesfrom software houses of Pakistan. In WHICEB 2016, Wuhan, China.

Hasan, M. S. M. S. (2017). Examining the effects of challenges faced in green construction on project outcomes: A Chinese perspective. International Journal of Engineering and Technology, 6(4), 315-321. https://doi.org/10.7763/IJET.2017.V9.990

Hedges, L. V., \& Olkin, I. (1985). Statistical methods for metaanalysis. New York: Academic Press, Inc.

Horman, M. J., \& Kenley, R. (2005). Quantifying levels of wasted time in construction with meta-analysis. Journal of Construction Engineering and Management, 131(1), 52-61. https://doi.org/10.1061/(ASCE)0733-9364(2005)131:1(52)

Hu, K., \& Zhang, R. (2016). Empirical research on influencing factors of highway project performance based on SEM. Engineering Economy, 26(3), 15-19.

Hunter, J. E., \& Schmidt, F. L. (2004). Methods of meta-analysis: Correcting error and bias in research findings. Thousand Oaks, CA, US: Sage Publications, Inc.

https://doi.org/10.4135/9781412985031

Hwang, B. G., \& Ng, H. B. (2016). Project network management: risks and contributors from the viewpoint of contractors and sub-contractors. Technological and Economic Development of Economy, 22(4), 631-648.

https://doi.org/10.3846/20294913.2015.1067847

Idiake, J. E., Oke, A. A., \& Shittu, A. A. (2015). Analysis of cost and quality relationship of private building projects in Abuja, Nigeria. International Journal of Construction Engineering and Management, 4(2), 35-43.

Ikediashi, D. I., \& Ogwueleka, A. C. (2016). Assessing the use of ICT systems and their impact on construction project performance in the Nigerian construction industry. Journal of Engineering, Design and Technology, 14(2), 252-276. https://doi.org/10.1108/JEDT-08-2014-0047

Iqbal, S., Choudhry, R. M., Holschemacher, K., Ali, A., \& Tamošaitienè, J. (2015). Risk management in construction projects. Technological and Economic Development of Economy, 21(1), 65-78. https://doi.org/10.3846/20294913.2014.994582

Isaac, S., \& Edrei, T. (2016). A statistical model for dynamic safety risk control on construction sites. Automation in Construction, 63(18), 66-78.

https://doi.org/10.1016/j.autcon.2015.12.006
Jaśkowski, P. (2015). Methodology for enhancing reliability of predictive project schedules in construction. Eksploatacja $i$ Niezawodnosc [Maintenance and Reliability], 17(3), 470-479. https://doi.org/10.17531/ein.2015.3.20

Jaśkowski, P., \& Biruk, S. (2011). The method for improving stability of construction project schedules through buffer allocation. Technological and Economic Development of Economy, 17(3), 429-444. https://doi.org/10.3846/20294913.2011.580587

Jiang, W. (2012). Review and implementation process of metaanalysis in management research. Journal of Zhejiang University (Humanities and Social Sciences), 42(5), 144-156.

Jin, Y. C. (2015). Minimizing total weighted completion time under makespan constraint for two-agent scheduling with jobdependent aging effects. Computers \& Industrial Engineering, 83(C), 237-243. https://doi.org/10.1016/j.cie.2015.02.024

Jin, H., Shen, L., \& Wang, Z. (2018). Mapping the influence of project management on project cost. KSCE Journal of Civil Engineering, 22(9), 3183-3195.

https://doi.org/10.1007/s12205-018-0397-8

Khamooshi, H., \& Cioffi, D. F. (2013). Uncertainty in task duration and cost estimates: Fusion of probabilistic forecasts and deterministic scheduling. Journal of Construction Engineering and Management, 139(5), 488-497. https://doi.org/10.1061/(ASCE)CO.1943-7862.0000616

Kiew, P. N., Ismail, S., \& Yusof, A. M. (2016). Integration of quality management system in the Malaysian construction industry. The Journal of Organizational Management Studies, 117211. https://doi.org/10.5171/2016.117211

Kim, D. Y., Kim, H., Han, S. H., \& Park, H. (2009). Structuring the prediction model of project performance for international construction projects: A comparative analysis. Expert Systems with Applications, 36(2), 1961-1971. https://doi.org/10.1016/j.eswa.2007.12.048

King, D. R., Dalton, D. R., Daily, C. M., \& Covin, J. G. (2004). Meta-analyses of post-acquisition performance: Indications of unidentified moderators. Strategic Management Journal, 25(2), 187-200. https://doi.org/10.1002/smj.371

Li, M., Yu, H., Jin, H., \& Liu, P. (2018). Methodologies of safety risk control for China's metro construction based on BIM. Safety Science, 110, 418-426.

https://doi.org/10.1016/j.ssci.2018.03.026

Liberatore, M. J., \& Pollack-Johnson, B. (2013). Improving project management Decision making by modeling quality, time, and cost continuously. IEEE Transactions on Engineering Management, 60(3), 518-528.

https://doi.org/10.1109/TEM.2012.2219586

Lim, C. S., \& Mohamed, M. Z. (1999). Criteria of project success: an exploratory re-examination. International Journal of Project Management, 17(4), 243-248.

https://doi.org/10.1016/S0263-7863(98)00040-4

Lin, C. W. R., \& Hsiau, H. J. (2010). A genetic algorithm approach for optimizing chemical towers construction project scheduling with dynamic resources constraints. International Journal of Industrial Engineering Theory Applications \& Practice, 17(2), 128-141.

Lines, B. C., Sullivan, K. T., Smithwick, J. B., \& Mischung, J. (2015). Overcoming resistance to change in engineering and construction: Change management factors for owner organizations. International Journal of Project Management, 33(5), 1170-1179. https://doi.org/10.1016/j.ijproman.2015.01.008

Lipsey, M. W., \& Wilson, D. B. (2001). The way in which intervention studies have "personality" and why it is important to meta-analysis. Evaluation \& The Health Professions, 24(3), 236-254. https://doi.org/10.1177/016327870102400302 
Littau, P., Jyothi Jujagiri, N., \& Adlbrecht, G. (2010). 25 years of stakeholder theory in project management literature (19842009). Project Management Journal, 41(4), 17-29.

https://doi.org/10.1002/pmj.20195

Liu, S. (2016). How the user liaison's understanding of development processes moderates the effects of user-related and project management risks on IT project performance. Information \& Management, 53(1), 122-134.

https://doi.org/10.1016/j.im.2015.09.004

Liu, J., Xie, Q., Xia, B., \& Bridge, A. J. (2017). Impact of design risk on the performance of design-build projects. Journal of Construction Engineering and Management, 143(6), 04017010. https://doi.org/10.1061/(ASCE)CO.1943-7862.0001299

Liu, L., Borman, M., \& Gao, J. (2014). Delivering complex engineering projects: Reexamining organizational control theory. International Journal of Project Management, 32(5), 791-802. https://doi.org/10.1016/j.ijproman.2013.10.006

Cooper, H., Hedges, L. V., \& Valentine, J. C. (2009). The hndbook of research synthesis and meta-analysis ( $2^{\text {nd }}$ ed.). New York: Russell Sage Foundation.

Mann, C. C. (1994). Can meta-analysis make policy? Science, 266, 960-962. https://doi.org/10.1126/science.7973676

Mao, Y., \& Xu, T. (2011). Research of 4M1E's effect on engineering quality based on structural equation model. Systems Engineering Procedia, 1, 213-220.

https://doi.org/10.1016/j.sepro.2011.08.034

Marzouk, M. M., \& El-Rasas, T. I. (2014). Analyzing delay causes in Egyptian construction projects. Journal of Advanced Research, 5(1), 49-55. https://doi.org/10.1016/j.jare.2012.11.005

Mclean, T., Mcgovern, T., \& Davie, S. (2015). Management accounting, engineering and the management of company growth: Clarke Chapman, 1864-1914. British Accounting Review, 47(2), 177-190. https://doi.org/10.1016/j.bar.2013.11.001

Mohammed, K. A., \& Isah, A. D. (2012). Causes of delay in Nigeria construction industry. Interdisciplinary Journal of Contemporary Research in Business, 4(2), 758-794.

Mok, K. Y., Shen, G. Q., \& Yang, J. (2015). Stakeholder management studies in mega construction projects: A review and future directions. International Journal of Project Management, 33(2), 446-457.

https://doi.org/10.1016/j.ijproman.2014.08.007

Molenaar, K. R., \& Dai, Q. T. (2014). Exploring critical delivery selection risk factors for transportation design and construction projects. Engineering Construction \& Architectural Management, 21(6), 631-647.

https://doi.org/10.1108/ECAM-11-2013-0103

Monghasemi, S., Nikoo, M. R., Fasaee, M. A. K., \& Adamowski, J. (2015). A novel multi criteria decision making model for optimizing time-cost-quality trade-off problems in construction projects. Expert Systems with Applications, 42(6), 30893104. https://doi.org/10.1016/j.eswa.2014.11.032

Mota, J., \& de Castro, L. M. (2017). Embedding of a new business as a cumulative process of combining different but complementary types of projects: The case of a project-based firm. Industrial Marketing Management, 16(9), 124-138. https://doi.org/10.1016/j.indmarman.2017.12.003

Müller, R., \& Turner, J. R. (2007). Matching the project manager's leadership style to project type. International Journal of Project Management, 25(1), 21-32.

https://doi.org/10.1016/j.ijproman.2006.04.003

Musa, M. M., Amirudin, R. B., Sofield, T., \& Musa, M. A. (2015). Influence of external environmental factors on the success of public housing projects in developing countries. Construction Economics and Building, 15(4), 30-34.

https://doi.org/10.5130/AJCEB.v15i4.4514
Nam, T. D., Duc, D. N., \& Duy, N. V. (2016). Factors affecting ODA project performance: The case of urban railway projects in Vietnam. International Journal of Economics and Finance, 8(11), 167-174. https://doi.org/10.5539/ijef.v8n11p167

Nguyen, H. T., \& Hadikusumo, B. (2017). Impacts of human resource development on engineering, procurement, and construction project success. Built Environment Project and Asset Management, 7(1), 73-85.

https://doi.org/10.1108/BEPAM-04-2016-0010

Nitithamyong, P., Skibniewski, M. J., \& Clark, A. J. (2007). Key success/failure factors and their impacts on system performance of Web-based project management systems in construction. Electronic Journal of Information Technology in Construction, 12, 39-59.

Olechowski, A., Oehmen, J., Seering, W., \& Ben-Daya, M. (2016). The professionalization of risk management: What role can the ISO 31000 risk management principles play? International Journal of Project Management, 34(8), 1568-1578. https://doi.org/10.1016/j.ijproman.2016.08.002

Petty, M. M., McGee, G. W., \& Cavender, J. W. (1984). A metaanalysis of the relationships between individual job satisfaction and individual performance. Academy of Management Review, 9(4), 712-721.

https://doi.org/10.5465/amr.1984.4277608

Pimchangthong, D., \& Boonjing, V. (2017). Effects of risk management practice on the success of IT project. Procedia Engineering, 182, 579-586.

https://doi.org/10.1016/j.proeng.2017.03.158

Pinto, J. K., \& Slevin, D. P. (2013). Critical factors in successful project implementation. IEEE Transactions on Engineering Management, EM-34(1), 22-27.

https://doi.org/10.1109/TEM.1987.6498856

Preethi S, \& Monisha, M. (2017). Project management and its effects of quality control in construction sector. International Journal of Engineering and Management Research, 7(2), 92-96.

Qureshi, S., Qureshi, S. M., Ullah, M., Memon, M. S., \& Siddiqui, M. A. (2017). Assessment of the extent of implementation of quality management system (QMS) and cost of quality (COQ) concepts - A case from a developing country. Journal of Engineering Research, 14(2), 145-155.

https://doi.org/10.24200/tjer.vol14iss2pp145-155

Rao, P. S., Viswanadhan, K. G., \& Raghunandana, K. (2015). Best practices for quality improvement - Lessons from top ranked engineering institutions. International Education Studies, 8(11), 169-183. https://doi.org/10.5539/ies.v8n11p169

Razo, L., Ramos, F., \& Occello, M. (2010, 28 September - 1 October 2010). METAOSE: Meta-analysis for agent oriented software engineering. In 2010 IEEE Electronics, Robotics and Automotive Mechanics Conference. Morelos, Mexico. https://doi.org/10.1109/CERMA.2010.33

Reeves-Latour, M., \& Morselli, C. (2016). Bid-rigging networks and state-corporate crime in the construction industry. Social Networks, 51, 158-170.

https://doi.org/10.1016/j.socnet.2016.10.003

Russell, M. M., Liu, M., Howell, G., \& Hsiang, S. M. (2015). Case studies of the allocation and reduction of time buffer through use of the last planner system. Journal of Construction Engineering and Management, 141(2), 04014068. https://doi.org/10.1061/(ASCE)CO.1943-7862.0000900

Safapour, E., Kermanshachi, S., Habibi, M., \& Shane, J. (2018, April). Resource-based exploratory analysis of project complexity impact on phase-based cost performance behavior. In Construction Research Congress 2018. New Orleans, Louisiana, USA. https://doi.org/10.1061/9780784481271.043 
Sambasivan, M., \& Soon, Y. W. (2007). Causes and effects of delays in Malaysian construction industry. International Journal of Project Management, 25(5), 517-526.

https://doi.org/10.1016/j.ijproman.2006.11.007

Sambasivan, M., Deepak, T. J., Salim, A. N., \& Ponniah, V. (2017). Analysis of delays in Tanzanian construction industry. Engineering, Construction and Architectural Management, 24(2), 308-325. https://doi.org/10.1108/ECAM-09-2015-0145

Sanchez, O. P., \& Terlizzi, M. A. (2017). Cost and time project management success factors for information systems development projects. International Journal of Project Management, 35(8), 1608-1626.

https://doi.org/10.1016/j.ijproman.2017.09.007

Sarigiannidis, L., \& Chatzoglou, P. D. (2014). Quality vs risk: An investigation of their relationship in software development projects. International Journal of Project Management, 32(6), 1073-1082. https://doi.org/10.1016/j.ijproman.2013.11.001

Schuh, G., Prote, J. P., Luckert, M., Basse, F., Thomson, V., \& Mazurek, W. (2018). Adaptive design of engineering change management in highly iterative product development. Procedia CIRP, 70, 72-77. https://doi.org/10.1016/j.procir.2018.02.016

Semab, S., Khan, A., \& Shah, F. A. (2017). Study on delaying factors affecting the success of construction projects in Pakistan; Role of project intervention as moderator. Journal of Administrative and Business Sciences, 2(2).

Smith, P. (2016). Global professional standards for project cost management. Procedia - Social and Behavioral Sciences, 226, 124-131. https://doi.org/10.1016/j.sbspro.2016.06.170

Springer, L., Stanne, M. E., \& Donovan, S. S. (1999). Effects of small-group learning on undergraduates in science, mathematics, engineering, and technology: A meta-analysis. Review of Educational Research, 69(1), 21-51.

https://doi.org/10.3102/00346543069001021

Stajkovic, A. D., \& Luthans, F. (2003). Behavioral management and task performance in organizations: Conceptual background, meta-analysis, and test of alternative models. Personnel Psychology, 56(1), 155-194. https://doi.org/10.1111/j.1744-6570.2003.tb00147.x

Sullivan, K. T. (2011). Quality management programs in the construction industry: Best value compared with other methodologies. Journal of Management in Engineering, 27(4), 210219. https://doi.org/10.1061/(ASCE)ME.1943-5479.0000054

Sun, H., Shen, K.-k., \& Fan, Z.-q. (2012). Analysis of factors influencing PPP project performance based on SEM. Journal of Tianjin University (Social Sciences), 14(6), 513-519.

Suprapto, M., Bakker, H. L. M., Mooi, H. G., \& Hertogh, M. J. C. M. (2016). How do contract types and incentives matter to project performance? International Journal of Project Management, 34(6), 1071-1087.

https://doi.org/10.1016/j.ijproman.2015.08.003

Teller, J., \& Kock, A. (2013). An empirical investigation on how portfolio risk management influences project portfolio success. International Journal of Project Management, 31(6), 817829. https://doi.org/10.1016/j.ijproman.2012.11.012

Thoedtida, T. (2014). Fuzzy critical chain risk management for quantifying impact of variation in non-critical activity duration on project duration. International Journal of Project Organisation and Management, 6(1/2), 48-66.

https://doi.org/10.1504/IJPOM.2014.059744
Toor, S. U. R., \& Ogunlana, S. O. (2009). Construction professionals' perception of critical success factors for large - scale construction projects. Construction Innovation, 9(2), 149-167. https://doi.org/10.1108/14714170910950803

Toutounchian, S., Abbaspour, M., Dana, T., \& Abedi, Z. (2018). Design of a safety cost estimation parametric model in oil and gas engineering, procurement and construction contracts. Safety Science, 106, 35-46.

https://doi.org/10.1016/j.ssci.2017.12.015

Wang, Y. R., Yu, C. Y., \& Chan, H. H. (2012). Predicting construction cost and schedule success using artificial neural networks ensemble and support vector machines classification models. International Journal of Project Management, 30(4), 470-478. https://doi.org/10.1016/j.ijproman.2011.09.002

Wang, X., Xia, N., Zhang, Z., Wu, C., \& Liu, B. (2017). Human safety risks and their interactions in China's subways: Stakeholder perspectives. Journal of Management in Engineering, 33(5), 05017004.

https://doi.org/10.1061/(ASCE)ME.1943-5479.0000544

Weiss, M., Hoegl, M., \& Gibbert, M. (2017). How does material resource adequacy affect innovation project performance? A meta-analysis. Journal of Product Innovation Management, 34(6), 842-863. https://doi.org/10.1111/jpim.12368

Wilson, R. (2015). Mastering project time management, cost control, and quality management: Proven methods for controlling the three elements that define project deliverables. London: Pearson FT Press.

Wu, G., Duan, K., Zuo, J., Yang, J., \& Wen, S. (2016). System dynamics model and simulation of employee work-family conflict in the construction industry. International Journal of Environmental Research \& Public Health, 13(11), 1059. https://doi.org/10.3390/ijerph13111059

Xia, N., Zou, P. X. W., Griffin, M. A., Wang, X., \& Zhong, R. (2018). Towards integrating construction risk management and stakeholder management: A systematic literature review and future research agendas. International Journal of Project Management, 36(5), 701-715.

https://doi.org/10.1016/j.ijproman.2018.03.006

Xie, X., \& Guo, D. (2017). Human factors risk assessment and management: process safety in engineering. Process Safety \& Environmental Protection, 113, 467-482. https://doi.org/10.1016/j.psep.2017.11.018

Yang, L.-R., Chen, J.-H., \& Huang, C.-F. (2013). A comprehensive framework for evaluating key project requirements. Journal of Civil Engineering and Management, 19(Sup. 1), S91S105. https://doi.org/10.3846/13923730.2013.801903

Zhang, Y., Liu, S., Tan, J., Jiang, G., \& Zhu, Q. (2018). Effects of risks on the performance of business process outsourcing projects: The moderating roles of knowledge management capabilities. International Journal of Project Management, 36(4), 627-639. https://doi.org/10.1016/j.ijproman.2018.02.002

Zhao, X. (2017). A scientometric review of global BIM research: Analysis and visualization. Automation in Construction, 80, 37-47. https://doi.org/10.1016/j.autcon.2017.04.002 


\section{APPENDIX}

\section{Results of meta-analysis}

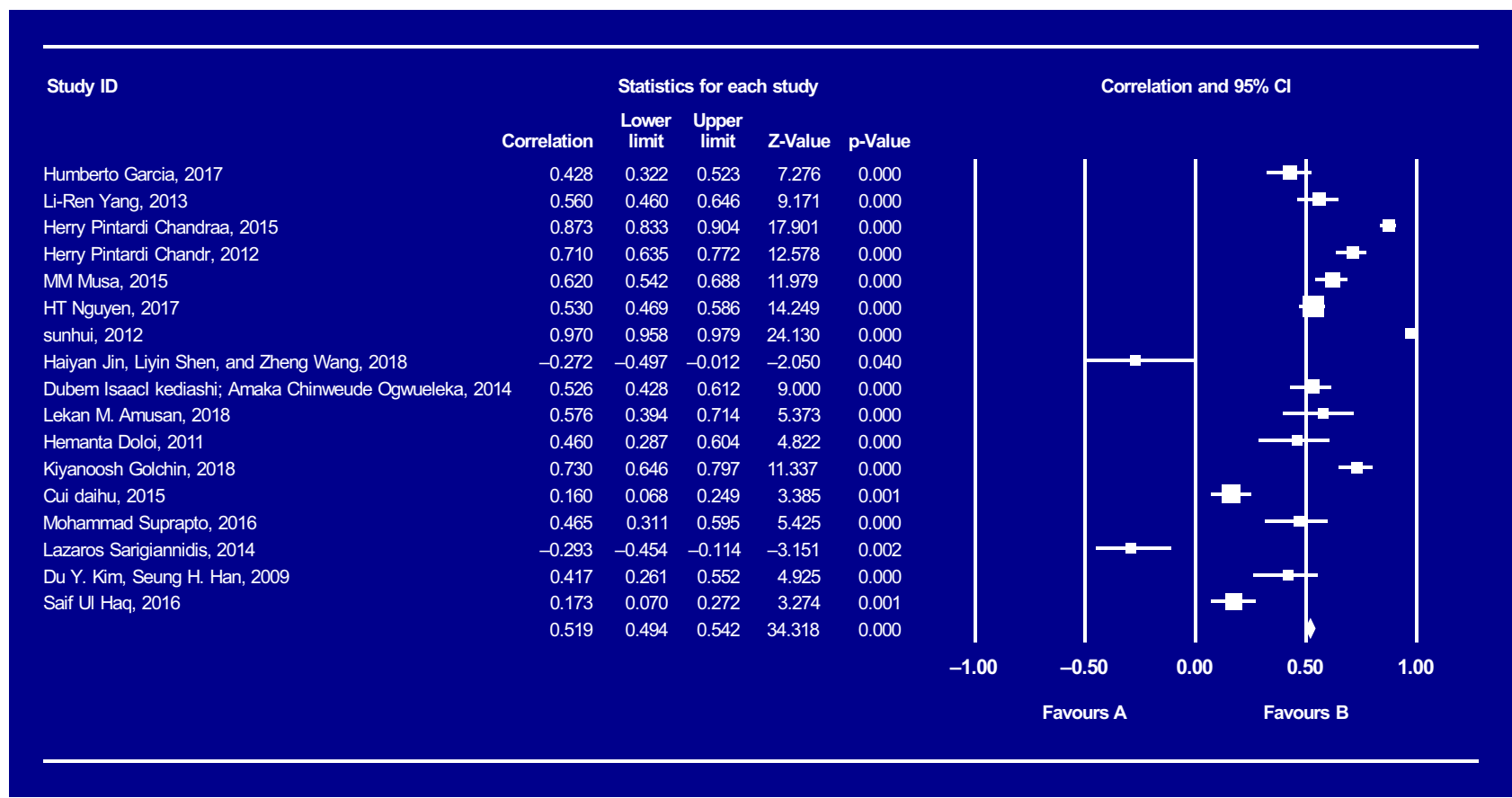

Figure A1. Results of meta-analysis (Quality)

Study ID

Humberto Garcia, 2017

Sameeda Semab, 2017

Li-Ren Yang, 2013

Herry Pintardi Chandraa, 2015

Herry Pintardi Chandr, 2012

Amgad Badewi

MM Musa, 2015

HT Nguyen, 2017

sunhui, 2012

hukai, 2016

Dubem Isaacl kediashi; Amaka Chinweude Ogmueleka, 2014

Lekan M. Amusan, 2018

Kiyanoosh Golchin, 2018

Cui daihu, 2015
Statistics for each study

\section{Lower Upper}

Correlation

0.398

0.64

$\begin{array}{llll}0.804 & 0.745 & 0.850 & 14.765\end{array}$

$\begin{array}{llll}0.630 & 0.539 & 0.706 & 10.511\end{array}$

$\begin{array}{llll}0.810 & 0.767 & 0.846 & 19.423\end{array}$

$\begin{array}{llll}0.700 & 0.634 & 0.756 & 14.330\end{array}$

$\begin{array}{lllll}0.830 & 0.803 & 0.854 & 28.688\end{array}$

$\begin{array}{llll}-0.530 & -0.641 & -0.397 & -6.806\end{array}$

$\begin{array}{llll}-0.580 & -0.680 & -0.459 & -7.810\end{array}$

$\begin{array}{llll}0.307 & 0.188 & 0.417 & 4.884\end{array}$

$\begin{array}{lllll}0.796 & 0.690 & 0.869 & 8.902\end{array}$

$\begin{array}{llll}0.830 & 0.773 & 0.874 & 14.503\end{array}$

$\begin{array}{llll}0.150 & 0.058 & 0.240 & 3.170\end{array}$

0.618

$\begin{array}{cc} & \\ \text { alue } & \text { p-Value } \\ .701 & 0.000 \\ 359 & 0.000 \\ .27 & 0.000 \\ 765 & 0.000 \\ .511 & 0.000 \\ .23 & 0.000 \\ 330 & 0.000 \\ 688 & 0.000 \\ 806 & 0.000 \\ 810 & 0.000 \\ 884 & 0.000 \\ 902 & 0.000 \\ 503 & 0.000 \\ 170 & 0.002 \\ 246 & 0.000 \\ & \end{array}$

Correlation and $95 \% \mathrm{Cl}$
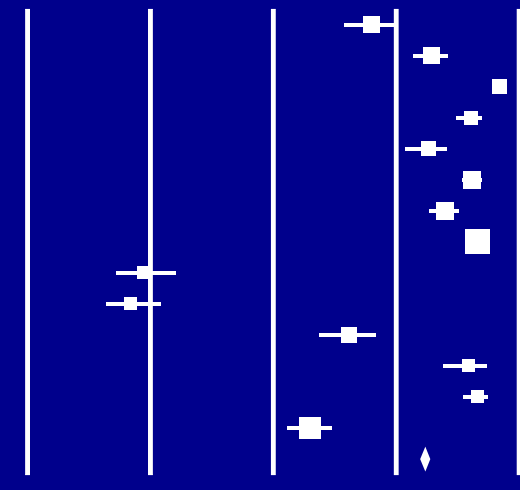

1.00

Figure A2. Results of meta-analysis (Duration) 
Study ID

Humberto Garcia, 2017

Li-Ren Yang, 2013

Herry Pintardi Chandraa, 2015

Herry Pintardi Chandr, 2012

Amgad Badewi

MM Musa, 2015

HT Nguyen, 2017

Mohammed Shareef M. S. Hasan, 2017

sunhui, 2012

hukai, 2016

Sambasivan M, 2017

Dubem Isaacl kediashi; Amaka Chinweude Ogwueleka, 2014

Lekan M. Amusan, 2018

Du Y. Kim, Seung H. Han, 2009

\section{Statistics for each study}

Lower Upper

Correlation

0.497

$\begin{array}{ll}0.399 & 0.584\end{array}$

$0.870 \quad 0.833-0.899$

$\begin{array}{llll}0.876 & 0.837 & 0.906 \quad 18.071\end{array}$

$\begin{array}{lllll}0.580 & 0.481 & 0.664 & 9.392 & 0.000\end{array}$

$\begin{array}{lllll}0.850 & 0.815 & 0.879 & 21.648 & 0.000\end{array}$

$\begin{array}{lllll}0.610 & 0.530 & 0.679 & 11.713 & 0.000\end{array}$

$\begin{array}{lllll}0.560 & 0.502 & 0.613 & 15.280 & 0.000\end{array}$

$\begin{array}{lllll}0.350 & 0.258 & 0.436 & 7.058 & 0.000\end{array}$

$\begin{array}{lllll}-0.550 & -0.657 & -0.421 & -7.132 & 0.000\end{array}$

$\begin{array}{lllll}-0.450 & -0.572 & -0.308 & -5.715 & 0.000\end{array}$

$\begin{array}{lllll}0.590 & 0.512 & 0.658 & 11.835 & 0.000\end{array}$

$\begin{array}{lllll}0.441 & 0.333 & 0.538 & 7.289 & 0.000\end{array}$

$\begin{array}{lllll}0.656 & 0.498 & 0.772 & 6.432 & 0.000\end{array}$

$\begin{array}{lllll}0.457 & 0.307 & 0.585 & 5.473 & 0.000\end{array}$

$\begin{array}{lllll}0.563 & 0.539 & 0.585 & 36.961 & 0.000\end{array}$
Correlation and $95 \% \mathrm{Cl}$
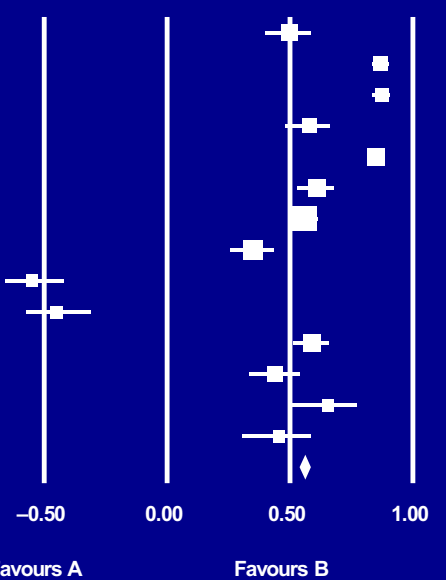

Figure A3. Results of meta-analysis (Cost)

Study ID

Humberto Garcia, 2017

Herry Pintardi Chandraa, 2015

Mohammed Shareef M. S. Hasan, 2017

sunhui, 2012

hukai, 2016

Sambasivan M, 2017

Junying Liu, 2017

Shan Liu, 2015

Yajun Zhang, 2018

Juliane Teller, 2013

Saif UI Haq, 2016

\section{Statistics for each study}

\section{Lower Upper}

Correlation

0.438

0.137

0.620

0.670

0.940

0.497

0.256

$-0.500$

$-0.310$

0.150

0.089

0.404 limit limit

0.333

$-0.009$

0.554

0.565

0.917

0.408

0.100

$-0.665$

$-0.463$

0.002

$-0.015$

0.369

\subsection{2}

0.278

0.679

0.753

0.957

0.577

0.400

$-0.288$

$-0.139$

0.291

0.191

0.438
Z-Value

7.472

1.834

14.002

9.350

20.491

9.524

3.174

$-4.255$

$-3.482$

1.988

1.672

20.219

p-Value
0.000
0.067
0.000
0.000
0.000
0.000
0.002
0.000
0.000
0.047
0.095
0.000

Correlation and $95 \% \mathrm{Cl}$
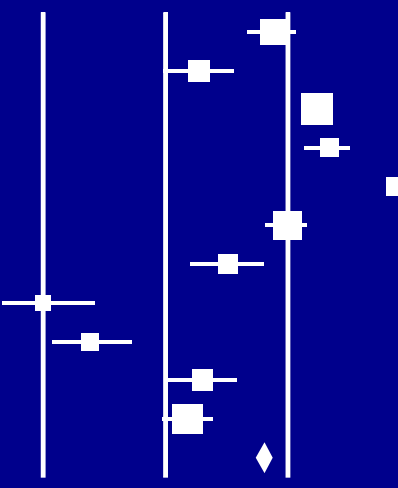

0.50

1.00 